\title{
Are $\mathrm{GABA}_{\mathrm{A}}$ Receptors Containing $\alpha 5$ Subunits Contributing to the Sedative Properties of Benzodiazepine Site Agonists?
}

\author{
Miroslav M Savić*,', Shengming Huang ${ }^{2}$, Roman Furtmüller ${ }^{3}$, Terry Clayton ${ }^{2}$, Sigismund Huck ${ }^{3}$, \\ Dragan I Obradović ${ }^{4}$, Nenad D Ugrešić ${ }^{\prime}$, Werner Sieghart ${ }^{3}$, Dubravko R Bokonjić ${ }^{5}$ and James M Cook $^{2}$ \\ 'Department of Pharmacology, Faculty of Pharmacy, University of Belgrade, Belgrade, Serbia; '2Department of Chemistry and Biochemistry, \\ University of Wisconsin-Milwaukee, Milwaukee, WI, USA; ${ }^{3}$ Center for Brain Research, Medical University Vienna, Vienna, Austria; ${ }^{4}$ Department of \\ Pharmacology, Medical Faculty, University of Belgrade, Belgrade, Serbia; ${ }^{5}$ National Poison Center, Military Medical Academy, Belgrade, Serbia
}

\begin{abstract}
Classical benzodiazepines (BZs) exert anxiolytic, sedative, hypnotic, muscle relaxant, anticonvulsive, and amnesic effects through potentiation of neurotransmission at GABA $A$ receptors containing $\alpha_{1}, \alpha_{2}, \alpha_{3}$ or $\alpha_{5}$ subunits. Genetic studies suggest that modulation at the $\alpha_{1}$ subunit contributes to much of the adverse effects of BZs, most notably sedation, ataxia, and amnesia. Hence, BZ site ligands functionally inactive at $\mathrm{GABA}_{A}$ receptors containing the $\alpha_{\mid}$subunit are considered to be promising leads for novel, anxioselective anxiolytics devoid of sedative properties. In pursuing this approach, we used two-electrode voltage clamp experiments in Xenopus oocytes expressing recombinant GABA $\mathrm{A}_{\mathrm{A}}$ receptor subtypes to investigate functional selectivity of three newly synthesized BZ site ligands and also compared their in vivo behavioral profiles. The compounds were functionally selective for $\alpha_{2^{-}}, \alpha_{3^{-}}$, and $\alpha_{5^{-}}$containing subtypes of $\mathrm{GABA}_{\mathrm{A}}$ receptors (SH-053-S-CH3 and SH-053-S-CH3-2'F) or essentially selective for $\alpha_{5}$ subtypes (SH-053-R-CH3). Possible influences on behavioral measures were tested in the elevated plus maze, spontaneous locomotor activity, and rotarod test, which are considered primarily predictive of the anxiolytic, sedative, and ataxic influence of BZs, respectively. The results confirmed the substantially diminished ataxic potential of BZ site agonists devoid of $\alpha$, subunit-mediated effects, with preserved anti-anxiety effects at $30 \mathrm{mg} / \mathrm{kg}$ of SH-053-S$\mathrm{CH} 3$ and $\mathrm{SH}-053-\mathrm{S}-\mathrm{CH} 3-2^{\prime} \mathrm{F}$. However, all three ligands, dosed at $30 \mathrm{mg} / \mathrm{kg}$, decreased spontaneous locomotor activity, suggesting that sedation may be partly dependent on activity mediated by $\alpha_{5}$-containing GABA receptors. Hence, it could be of importance to avoid substantial agonist activity at $\alpha_{5}$ receptors by candidate anxioselective anxiolytics, if clinical sedation is to be avoided. Neuropsychopharmacology (2008) 33, 332-339; doi: I0.1038/sj.npp. I 30 I403; published online 28 March 2007
\end{abstract}

Keywords: GABA ; benzodiazepine; sedation; anxiety; ataxia; subtype-selectivity

\section{INTRODUCTION}

Since their clinical introduction in the early 1960s, benzodiazepines (BZs) have been extensively prescribed worldwide to cope with anxiety, insomnia, muscle spasms, and epilepsy. The basic characterization of the diverse pharmacological effects of BZs: anxiolytic, sedative, hypnotic, muscle relaxant, anticonvulsive, and amnesic, has been considered to represent one of the major successes of behavioral pharmacology (Sanger et al, 2003). In recent years, much effort has been expended to improve the understanding of the molecular and neuronal substrates of these effects, with the final goal to clinically separate wanted from unwanted effects (Sieghart and Sperk, 2002). Among the latter effects, psychomotor and cognitive impairments are common, and more serious neuropsychiatric reactions

*Correspondence: Dr MM Savić, Department of Pharmacology, Faculty of Pharmacy, University of Belgrade, Vojvode Stepe 450, Belgrade I|221, Serbia, Tel: + 38| || 3970379 ext. 680, Fax: + 38 | I I 3972840, E-mail: miroslav@pharmacy.bg.ac.yu

Received 3 November 2006; revised I5 February 2007; accepted 23 February 2007 such as amnesic and aggressive episodes may occur (Lader, 1999).

BZs act as facilitators of fast inhibitory neurotransmission in the mammalian brain mediated through $\mathrm{GABA}_{\mathrm{A}}$ receptors, which are involved in the regulation of vigilance, anxiety, muscle tension, epileptogenic activity, and memory functions (Rudolph and Möhler, 2004). The vast majority of $\mathrm{GABA}_{\mathrm{A}}$ receptors are associations of two $\alpha$ subunits, two $\beta$ subunits, and a single $\gamma$ subunit, which form a central ion channel, and approximately $80 \%$ of all $\mathrm{GABA}_{\mathrm{A}}$ receptors contain a BZ-binding site located at the interface of the $\gamma_{2}$ subunit and the respective $\alpha$ subunit $\left(\alpha_{1}, \alpha_{2}, \alpha_{3}\right.$ or $\left.\alpha_{5}\right)$ (Chang et al, 1996; Sigel and Buhr, 1997). It has been postulated that the four $\mathrm{BZ}$ site-building $\alpha$ subunits, with their distinct patterns of anatomical distribution in the brain, participate differently in the various effects of BZs. Indeed, recent genetic and pharmacological studies pointed to the specific contribution of individual receptor subtypes to the spectrum of behavioral actions of $\mathrm{BZ}$ site ligands. Specifically, sedative effects of BZs were principally attributed to $\alpha_{1}$-containing $\mathrm{GABA}_{\mathrm{A}}$ receptor subtypes, anxiolytic actions to the $\alpha_{2}-/ \alpha_{3}$-containing receptors, anterograde amnesic effects to the $\alpha_{1} / \alpha_{5}$ subtypes, anticonvulsant 
activity partially to the $\alpha_{1}$-containing receptors, and muscle relaxant effects largely to $\alpha_{2}$-containing receptors (Atack et al, 2006a; Low et al, 2000; McKernan et al, 2000; Rudolph and Möhler, 2006; Rudolph et al, 1999). Moreover, it appears that L-838417, a ligand with zero efficacy at the $\alpha_{1}$ subtype, is unable to engender sedation in rodents (McKernan et al, 2000) or monkeys (Rowlett et al, 2005), and similar conclusions were drawn from behavioral experiments with other compounds functionally selective for receptors other than $\alpha_{1}$-containing receptors (Atack et al, 2006c; Dias et al, 2005; Licata et al, 2005). Since the $\alpha_{1}$-subunit is critically involved in much of the unwanted psychomotor activity of nonselective BZs, ' $\alpha_{1}$-neutral' agonists at $\mathrm{BZ}$ site are being pursued in the quest for anxioselective anxiolytics (Basile et al, 2004; Whiting, 2006).

To date, all apparently non-sedating $\mathrm{BZ}$ site ligands, which are devoid of activity at $\alpha_{1}$-containing $\mathrm{GABA}_{\mathrm{A}}$ receptors, engendered essentially antagonist (Atack et al, 2006c; Dias et al, 2005) or only partial agonist efficacy at $\alpha_{5^{-}}$ containing $\mathrm{GABA}_{\mathrm{A}}$ receptors (Griebel et al, 2001; McKernan et al, 2000). Therefore, it cannot be ruled out that substantial efficacy at $\alpha_{5}$-containing $\mathrm{GABA}_{\mathrm{A}}$ receptors may contribute to sedative effects. This is supported by data, which indicate the possibility of substantial motor influence by modulation of $\alpha 5$ subunit containing $\mathrm{GABA}_{\mathrm{A}}$ receptors. In the spinal cord, somatic and preganglionic motoneurons (lamina IX and lateral cell column) exhibited a moderate to strong staining for the $\alpha 5$ subunit (Bohlhalter et al, 1996). Knock-in mice with the $\mathrm{GABA}_{\mathrm{A}}$ receptor $\alpha 5$ subunit rendered insensitive to diazepam were refractory to development of tolerance to the sedative effect of diazepam dosed subchronically (van Rijnsoever et al, 2004). These two sets of evidence indicate that the motor influence of $\alpha 5$ $\mathrm{GABA}_{\mathrm{A}}$ receptor modulation, if present, is not necessarily an indirect consequence of the established effects on learning and memory processes (Collinson et al, 2002; Crestani et al, 2002). Hence, any activity changes seen with ligands possessing a substantial agonistic efficacy for $\alpha 5$ subunit containing $\mathrm{GABA}_{\mathrm{A}}$ receptors may be, at least partly, mediated by such receptors.

To test this hypothesis, we identified such ligands by using two-electrode voltage clamp experiments in Xenopus oocytes expressing recombinant $\mathrm{GABA}_{\mathrm{A}}$ receptor subtypes. Three newly synthesized $\mathrm{BZ}$ site ligands turned out to be functionally selective for $\alpha_{2}, \alpha_{3}$, and $\alpha_{5}$ subtypes of $\mathrm{GABA}_{\mathrm{A}}$ receptors (SH-053-S-CH3 and SH-053-S-CH3-2 ${ }^{\prime}$ ) , or essentially selective for the $\alpha_{5}$ subtypes (SH-053-R-CH3). We then compared their in vivo behavioral profiles with that of the classical nonselective agonist diazepam. Possible influences on behavioral measures were tested in the elevated plus maze (EPM), spontaneous locomotor activity (SLA) and rotarod test that are considered primarily predictive of the anxiolytic, sedative and ataxic influence of BZs, respectively.

\section{MATERIALS AND METHODS}

\section{Drugs}

SH-053-S-CH3 and SH-053-R-CH3 (the $(S)$ and $(R)$ stereoisomer, respectively, of 8-ethynyl-4-methyl-6-phenyl-4H-2, 5,10b-triaza-benzo[e]azulene-3-carboxylic acid ethyl ester; structures given in Figure 1) as well as $\mathrm{SH}-053-\mathrm{S}-\mathrm{CH} 3-2^{\prime} \mathrm{F}$ (the $(S)$ stereoisomer of 8-ethynyl-6-(2-fluorophenyl)4-methyl-4H-2,5,10b-triaza-benzo[e]azulene-3-carboxylic acid ethyl ester) were synthesized at the Department of Chemistry and Biochemistry, University of WisconsinMilwaukee. Diazepam for behavioral studies was obtained from Galenika (Belgrade, Serbia).

\section{Electrophysiological Experiments}

Cloning of $\mathrm{GABA}_{\mathrm{A}}$ receptor subunits $\alpha 1, \beta 3$, and $\gamma 2$ into pCDM8 expression vectors (Invitrogen, CA) has been described elsewhere (Fuchs et al, 1995). cDNAs for subunits $\alpha 2, \alpha 3$, and $\alpha 5$ were gifts from $\mathrm{P}$ Malherbe and were subcloned into pCI vector. After linearizing the cDNA vectors with appropriate restriction endonucleases, capped transcripts were produced using the mMessage mMachine T7 transcription kit (Ambion, TX). The capped transcripts were polyadenylated using yeast poly(A) polymerase (USB, $\mathrm{OH})$ and were diluted and stored in diethylpyrocarbonatetreated water at $-70^{\circ} \mathrm{C}$.

The methods used for isolating, culturing, injecting, and defolliculating of the oocytes were identical as described previously (Sigel, 1987; Sigel et al, 1990). Briefly, mature female Xenopus laevis (Nasco, WI) were anesthetized in a bath of ice-cold $0.17 \%$ Tricain (Ethyl-m-aminobenzoat, Sigma, MO) before decapitation and removal of the frog's ovary. Stage 5-6 oocytes with the follicle cell layer around them were singled out of the ovary using a platinum wire loop. Oocytes were stored and incubated at $18^{\circ} \mathrm{C}$ in modified Barths' medium (MB, containing $88 \mathrm{mM} \mathrm{NaCl}$, $10 \mathrm{mM}$ HEPES-NaOH ( $\mathrm{pH} 7.4$ ), $2.4 \mathrm{mM} \mathrm{NaHCO}_{3}, 1 \mathrm{mM} \mathrm{KCl}$, $\left.0.82 \mathrm{mM} \mathrm{MgSO}_{4}, 0.41 \mathrm{mM} \mathrm{CaCl}, 0.34 \mathrm{mM} \mathrm{Ca}\left(\mathrm{NO}_{3}\right)_{2}\right)$ that was supplemented with $100 \mathrm{U} / \mathrm{ml}$ penicillin and $100 \mu \mathrm{g} / \mathrm{ml}$

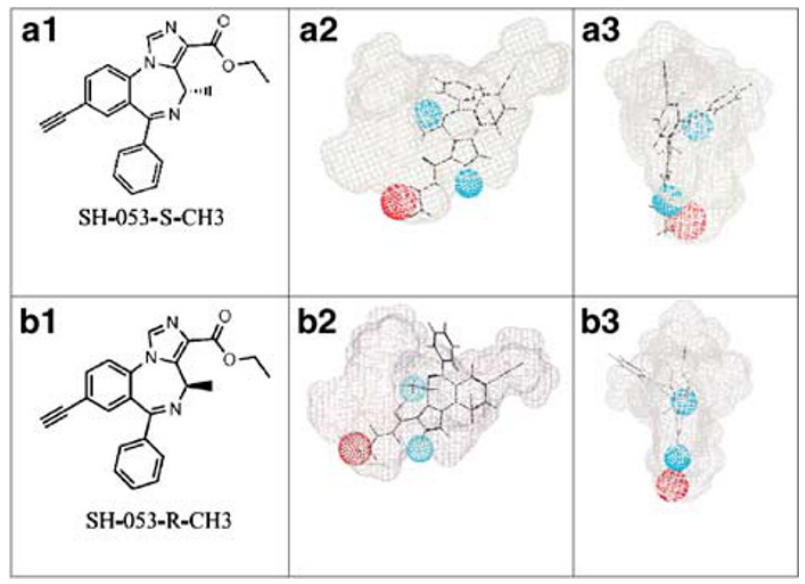

Figure I Structures and conformations of $\mathrm{SH}-053-\mathrm{S}-\mathrm{CH} 3(\mathrm{al}-\mathrm{a} 3)$ and $\mathrm{SH}-053-\mathrm{R}-\mathrm{CH} 3$ (bl-b3). The molecular modeling was carried out as described in Zhang et al (1995) and He et al (2000), and will not be reiterated here. $\mathrm{SH}-053-\mathrm{S}-\mathrm{CH}_{3}$ fits the pharmacophore within the included volume of the $\alpha 2$ subtype (a2); (a3) is the same image rotated $90^{\circ}$. It can be clearly seen that this conformer fits within the included volume. At (b2) $\mathrm{SH}-053-\mathrm{R}_{-} \mathrm{CH}_{3}$ fits the pharmacophore in the included volume of the $\alpha 2$ subtype; (b3) is the same image rotated $90^{\circ}$. The $\mathrm{R}_{-} \mathrm{CH}_{3}$ at the prochiral center C4 changes the conformation of the molecule causing the pendant 6-phenyl to stick outside the included volume; consequently, this ligand is not efficacious at the $\alpha 2$ subtype. It simply does not interact strongly with $\alpha 1, \alpha 2$, or $\alpha 3$ subtypes. 
streptomycin. Oocytes with follicle cell layers still around them were injected with a total of $2.25 \mathrm{ng}$ of cRNA. cRNA ratio used was $1: 1: 5$ for the $\alpha$ subunits, $\beta 3$, and $\gamma 2$, respectively. After injection of cRNA, oocytes were incubated for at least $36 \mathrm{~h}$ before the enveloping follicle cell layers were removed. To this end, oocytes were incubated for $20 \mathrm{~min}$ at $37^{\circ} \mathrm{C}$ in $\mathrm{MB}$ that contained $1 \mathrm{mg} / \mathrm{ml}$ collagenase type IA and $0.1 \mathrm{mg} / \mathrm{ml}$ trypsin inhibitor I-S (both Sigma). This was followed by osmotic shrinkage of the oocytes in doubly concentrated MB medium supplied with $4 \mathrm{mM} \mathrm{Na-EGTA}$ and manually removing the follicle cell layer. After peeling off the follicle cell layer, the cells were allowed to recover overnight before being used in electrophysiological experiments.

For electrophysiological recordings, oocytes were placed on a nylon grid in a bath of Xenopus Ringer solution (XR, containing $90 \mathrm{mM} \mathrm{NaCl}, 5 \mathrm{mM}$ HEPES- $\mathrm{NaOH}$ (pH 7.4), $1 \mathrm{mM} \mathrm{MgCl}_{2}, 1 \mathrm{mM} \mathrm{KCl}$, and $1 \mathrm{mM} \mathrm{CaCl}_{2}$ ). The oocytes were constantly washed by a flow of $6 \mathrm{ml} / \mathrm{min} \mathrm{XR}$, which could be switched to XR containing GABA and/or drugs. Drugs were diluted into XR from dimethylsulfoxide (DMSO) solutions resulting in a final concentration of $0.1 \%$ DMSO perfusing the oocytes. Drugs were preapplied for $30 \mathrm{~s}$ before the addition of GABA, which was coapplied with the drugs until a peak response was observed. Between two applications, oocytes were washed in XR for up to $15 \mathrm{~min}$ to ensure full recovery from desensitization. For current measurements, the oocytes were impaled with two microelectrodes (2$3 \mathrm{~m} \Omega$ ), which were filled with $2 \mathrm{mM} \mathrm{KCl}$. All recordings were performed at room temperature at a holding potential of $-60 \mathrm{mV}$ using a Warner OC-725C two-electrode voltage clamp (Warner Instruments, Hamden, CT). Data were digitized, recorded, and measured using a Digidata 1322A data acquisition system (Axon Instruments, Union City, $\mathrm{CA})$. Results of concentration response experiments were graphed using GraphPad Prism 4.00 (GraphPad Software, San Diego, CA). Data were graphed as mean \pm SEM of at least four oocytes from at least two batches.

\section{Behavioral Experiments}

Experiments were carried out on male Wistar rats (Military Farm, Belgrade, Serbia), weighing 200-240 g. All procedures in the study conformed to EEC Directive 86/609 and were approved by the Ethical Committee on Animal Experimentation of the Medical Faculty in Belgrade. The rats were housed in transparent plastic cages, six animals per cage, and had free access to pelleted food and tap water. The temperature of the animal room was $22 \pm 1^{\circ} \mathrm{C}$, the relative humidity $40-70 \%$, the illumination 120 lux, and the $12 / 12 \mathrm{~h}$ light/dark period (light on at 06:00). All handling and testing took place during the light phase of the diurnal cycle. Throughout the study the animals were used only once. All drugs were dissolved/suspended with the aid of sonication in a solvent containing $85 \%$ distilled water, $14 \%$ propylene glycol, and $1 \%$ Tween 80 , and were administered intraperitoneally in a volume of $1 \mathrm{ml} / \mathrm{kg}$.

\section{Behavior on the Elevated Plus Maze}

The apparatus was constructed of sheet metal, with a black rubber floor. It consisted of a maze elevated to a height of
$50 \mathrm{~cm}$ with two open $(50 \times 10 \mathrm{~cm})$ and two enclosed arms $(50 \times 10 \times 40 \mathrm{~cm})$, connected by a junction area (central platform) measured $10 \times 10 \mathrm{~cm}$. A ledge of sheet metal $(0.3 \mathrm{~cm}$ high) surrounding the open arms was added. The illumination in the experimental room consisted of one red neon tube fixed on the ceiling, giving light intensity of 10 lux on the surface of the arms.

The animals were tested $20 \mathrm{~min}$ after injection of drugs or solvent. At the beginning of the experiment, single rats were placed in the center of the maze, facing one of the enclosed arms, and their behavior was recorded for $5 \mathrm{~min}$. A digital camera was mounted above the maze and the image was transmitted to a notebook computer in the neighboring room, running the ANY-maze Video Tracking System software (Stoelting Co., Wood Dale, IL, USA). An entry into an open or closed arm was scored when $90 \%$ of the animal crossed the virtual line separating the central square of the maze from the arm, whereas an exit occurred when more than $90 \%$ of the animal left the respective arm. After each trial, the maze was cleaned with dry and wet towels.

\section{Measurement of Locomotor Activity}

Immediately after receiving the appropriate treatment, single rats were placed in a clear Plexiglas chamber $(40 \times 25 \times 35 \mathrm{~cm})$. Activity under dim red light (20lux) was recorded for a total of $45 \mathrm{~min}$, without any habituation period, using ANY-maze software (as described above). For purposes of improving data analysis, the central $20 \%$ of the chamber $\left(200 \mathrm{~cm}^{2}\right)$ was virtually set as a central zone. The minimum percentage of animal that must have been in the zone for an entry to occur was set at $70 \%$, and $50 \%$ of the animal must have remained in the zone for an exit not to occur.

\section{Rotarod Performance}

Rotarod test (Ugo Basile, Comerio, Italy) measured the capacity of the animal to maintain itself on the rod revolving 10 r.p.m. During two consecutive days, the rats were trained to walk on the revolving rod until they could complete three $180 \mathrm{~s}$ sessions (each day) without falling of. In the morning of the third day, the final selection was made. Only animals capable of remaining $180 \mathrm{~s}$ on the rod, without any fall, were chosen for further testing. The animals which were not able to remain on the rod for $180 \mathrm{~s}$ when tested $20 \mathrm{~min}$ after treatment were considered incapacitated.

\section{Statistical Analysis}

All numerical data presented in the figures were given as the mean \pm SEM. For electrophysiological data Student's $t$-test was used. Data from the EPM and activity assay were assessed by a one-way ANOVA. If the ANOVA was significant, each treatment condition was compared with control by a Dunnett's test $(\alpha=0.05)$. $\mathrm{ED}_{50}$ value for rotarod incapacitation was calculated by probit analysis according to the method of Litchfield and Wilcoxon. Statistical analyses were performed with ANY-maze software. 


\section{RESULTS}

\section{Electrophysiological Experiments}

In vitro data for $\mathrm{SH}-053-\mathrm{S}-\mathrm{CH} 3$ (Figure 2a) and $\mathrm{SH}-053-\mathrm{R}-$ $\mathrm{CH} 3$ (Figure $2 \mathrm{~b}$ ) demonstrated that at concentrations up to $1 \mu \mathrm{M}$ both ligands significantly and dose-dependently stimulated GABA EC3 response of $\alpha 5$-containing receptors up to 300 and $200 \%$ of control current, respectively. These compounds, thus, are high-efficacy agonists at the $\alpha 5$ containing $\mathrm{GABA}_{\mathrm{A}}$ receptors comparable to diazepam (see legend to Figure 2), with very low efficacies at $\alpha 1$ containing subtypes. However, although SH-053-S-CH3 exerted substantial potentiation of an EC3 GABA response at $\alpha 2$ and $\alpha 3$-containing $\mathrm{GABA}_{\mathrm{A}}$ receptors, the influence of SH-053-R$\mathrm{CH} 3$ at these receptors was comparable to its minor effect at the $\alpha 1$ subtype (cf. molecular modeling in Figure 1). The in vitro concentration-effect curves for $\mathrm{SH}-053-\mathrm{S}-\mathrm{CH} 3-2^{\prime} \mathrm{F}$ (Rowlett JK, Furtmüller R, Cook JM, unpublished results) were similar to those for SH-053-S-CH3, but with a higher magnitude of efficacies at the respective $\alpha 2, \alpha 3$,
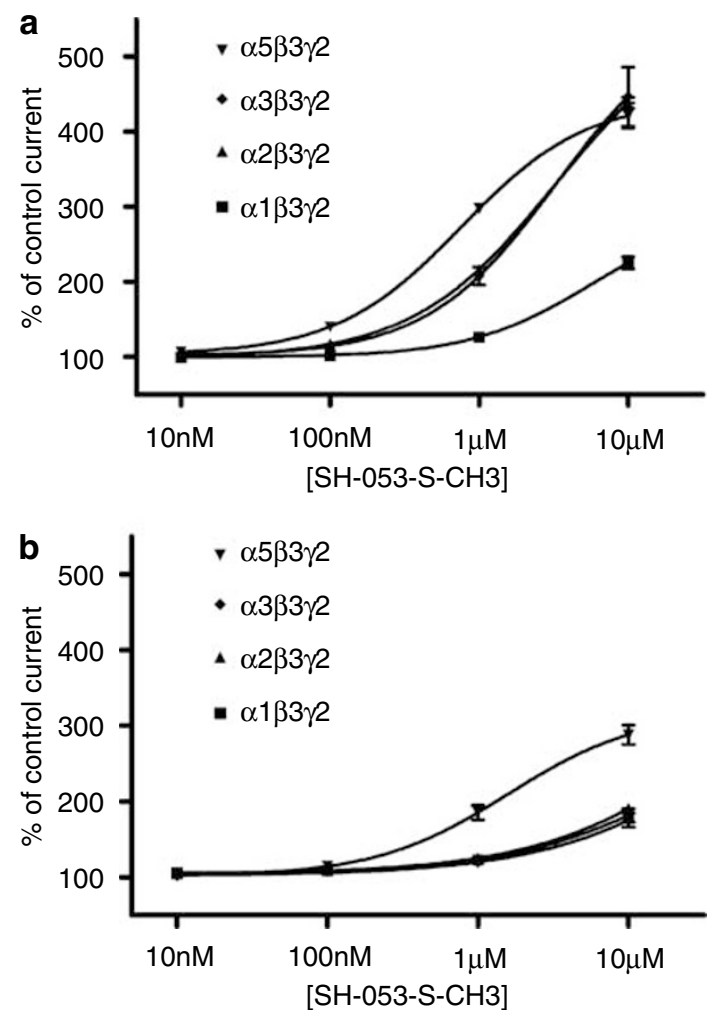

Figure 2 Concentration-effect curves for $\mathrm{SH}-053-\mathrm{S}-\mathrm{CH} 3$ (a) and $\mathrm{SH}$ 053-R- $-\mathrm{CH}_{3}$ (b) on $\alpha_{1} \beta_{3} \gamma_{2}, \alpha_{2} \beta_{3} \gamma_{2}, \alpha_{3} \beta_{3} \gamma_{2}$, and $\alpha_{5} \beta_{3} \gamma_{2}$ GABA $\mathrm{A}$ receptors, using an $\mathrm{EC}_{3}$ GABA concentration. Data points represent means $\pm S E M$ from at least four oocytes from $\geqslant 2$ batches. A concentration of I $\mu \mathrm{M} \mathrm{SH}$ $053-\mathrm{S}-\mathrm{CH} 3$ resulted in 126 $\pm 7,216 \pm 13,207 \pm 24$ and $297 \pm 11 \%$ of control current (at GABA EC ${ }_{3}$ ) in $\alpha_{1} \beta_{3} \gamma_{2}, \alpha_{2} \beta_{3} \gamma_{2}, \alpha_{3} \beta_{3} \gamma_{2}$, and $\alpha_{5} \beta_{3} \gamma_{2}$ receptors, respectively. A concentration of I $\mu \mathrm{M} \mathrm{SH}-053-\mathrm{R}-\mathrm{CH} 3$ resulted in $124 \pm 7,125 \pm 5,120 \pm 5$ and 186 $\pm 19 \%$ of control current in $\alpha_{1} \beta_{3} \gamma_{2}$, $\alpha_{2} \beta_{3} \gamma_{2}, \alpha_{3} \beta_{3} \gamma_{2}$, and $\alpha_{5} \beta_{3} \gamma_{2}$, respectively. All these values were significantly different from those of the respective control currents $(p<0.0$ I. Student's t-test). For comparison, I $\mu \mathrm{M}$ of diazepam (which in contrast to I $\mu \mathrm{M}$ of $\mathrm{SH}-053-\mathrm{S}-\mathrm{CH} 3$ and $\mathrm{SH}-053-\mathrm{R}-\mathrm{CH}_{3}$ produces maximal stimulation of GABA EC 3 current) resulted in $345 \pm 54,508 \pm 58,749 \pm 107$ and $420 \pm 30 \%$ of control current for $\alpha_{1} \beta_{3} \gamma_{2}, \alpha_{2} \beta_{3} \gamma_{2}, \alpha_{3} \beta_{3} \gamma_{2}$, and $\alpha_{5} \beta_{3} \gamma_{2}$ receptors, respectively. and $\alpha 5 \mathrm{GABA}_{\mathrm{A}}$ receptor subtypes in the concentration range $0.1-10 \mu \mathrm{M}$.

\section{Elevated Plus Maze}

SH-053-S-CH3. Activity-related parameters: The influence of treatment on closed arm entries did not reach statistical significance $(\mathrm{F}(4,27)=1.19, p=0.337)$; statistical analysis by ANOVA showed a significant effect of treatment neither on total arm entries $(F(4,27)=1.72, p=0.175)$ nor on total distance travelled $(\mathrm{F}(4,27)=1.80, p=0.157)$.

Anxiety-related parameters (Figure 3): There was a close to significant effect of treatment on distance travelled in open arms $(\mathrm{F}(4,27)=2.37, p=0.078)$ (Figure 3a). The overall influence of treatment on the percentage of open-arm entries has reached statistical significance $(\mathrm{F}(4,27)=3.13, \quad p=0.031) \quad$ (Figure $3 \mathrm{~b})$, Dunnett's test pointed to the anxiolytic influence of diazepam $(p=0.038)$ and SH-053-S-CH3 dosed at $30 \mathrm{mg} / \mathrm{kg} \quad(p=0.049)$. The influence on the percentage of time on open arms also was significant $(\mathrm{F}(4,27)=2.75, p=0.049)$ (Figure $3 \mathrm{c}$ ), but post hoc testing did not detect a significant effect of any single treatment.

SH-053-S-CH3-2'F. Activity-related parameters: Statistical evaluation by ANOVA did not show significant influences of treatment on closed-arm entries, total-arm entries or total distance travelled $((\mathrm{F}(4,45)=1.29, p=0.290),(\mathrm{F}(4,45)=0.13$, $p=0.969)$, and $(\mathrm{F}(4,45)=0.25, p=0.911)$, respectively).

Anxiety-related parameters (Figure 4): Although the influence of treatment on distance travelled in open arms was not significant $(\mathrm{F}(4,45)=1.92, p=0.124)$ (Figure 4a), the overall effect on the percentage of open arm entries (Figure $4 \mathrm{~b}$ ) and the percentage of time on open arms (Figure $4 \mathrm{c})$ has reached statistical significance $((\mathrm{F}(4,45)=$ $2.94, p=0.031)$ and $(\mathrm{F}(4,45)=2.92, p=0.031)$, respectively). For both of these parameters, post hoc testing revealed the equivalent influence of diazepam and SH-053-S-CH3 dosed at $30 \mathrm{mg} / \mathrm{kg}$ ( $p$ values 0.018 for the percentage of open-arm entries and 0.017 for the percentage of time on open arms).

$\mathrm{SH}-053-\mathrm{R}-\mathrm{CH} 3$. When tested at doses up to $30 \mathrm{mg} / \mathrm{kg}$, SH$053-R-\mathrm{CH} 3$ failed to induce any significant change of the measured EPM parameters (data not shown).

Locomotor activity assay. Whole chamber activity: An ANOVA showed a significant effect of treatment on total distance travelled during $45 \mathrm{~min}$ of monitoring $(\mathrm{F}(4,31)=3.86, p<0.001)$ (Figure 5, whole bars). According to Dunnett's test, the activity-decreasing effect of all four tested compounds (diazepam $1.25 \mathrm{mg} / \mathrm{kg}$, SH-053-S-CH3, SH-053-S-CH3-2'F and SH-053-R-CH3 at $30 \mathrm{mg} / \mathrm{kg}$ each) was significant related to solvent. When the ANOVA was applied on the $5 \mathrm{~min}$ intervals of travelled distance (Figure 6), it turned out that locomotor activity was significantly depressed in the time period 5-20 min ( $\mathrm{SH}-$ $053-\mathrm{S}-\mathrm{CH} 3 \quad 30 \mathrm{mg} / \mathrm{kg}$, SH-053-S-CH3-2'F $30 \mathrm{mg} / \mathrm{kg}$, and $\mathrm{SH}-053-\mathrm{R}-\mathrm{CH} 330 \mathrm{mg} / \mathrm{kg}$ ), whereas diazepam $1.25 \mathrm{mg} / \mathrm{kg}$ decreased locomotion in the period 5-15 min.

Central/peripheral distance: An ANOVA showed a significant effect of treatment on distance travelled in the arbitrarily set central parts of the chamber during $45 \mathrm{~min}$ of 

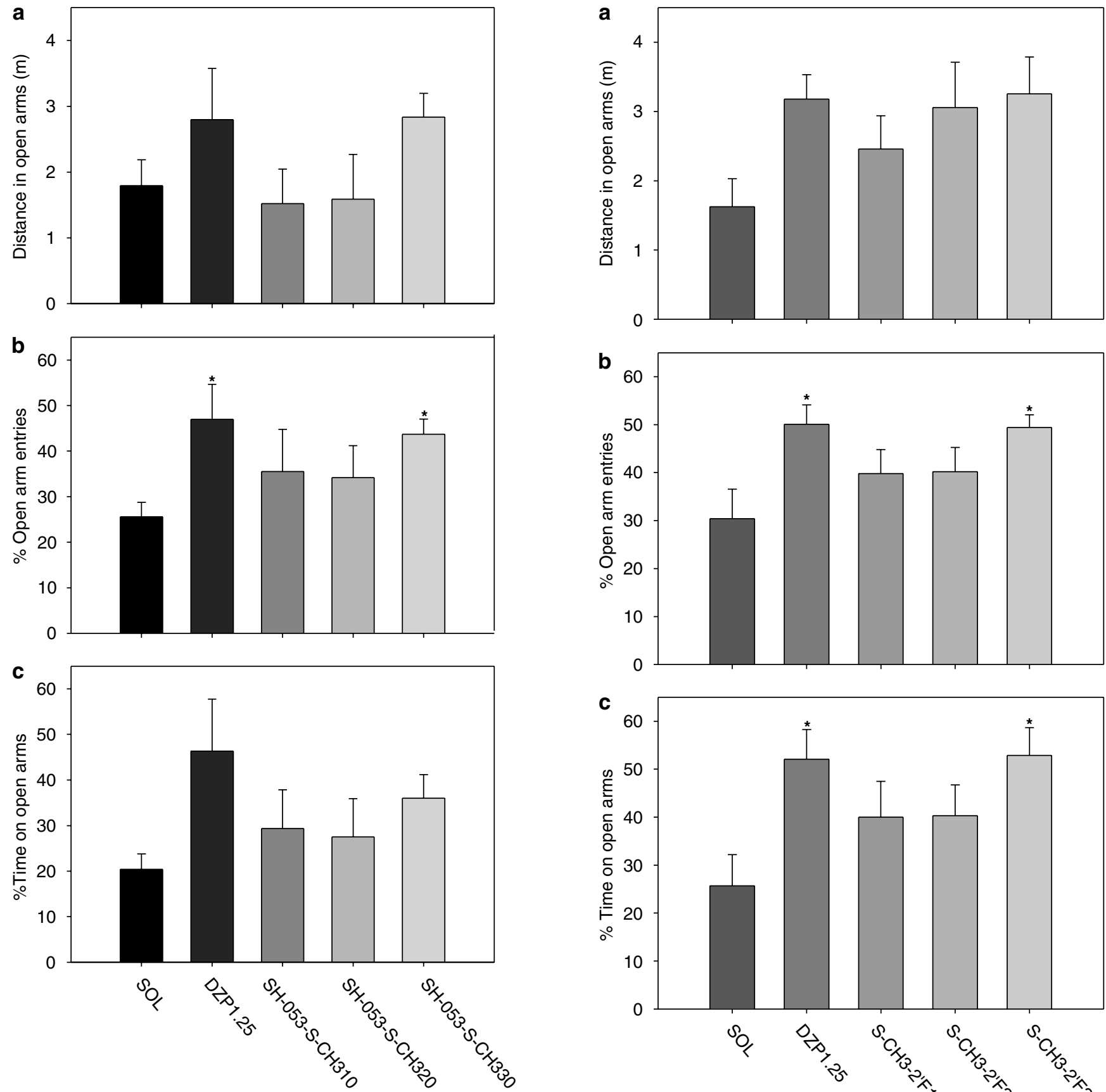

Figure 3 The effects of diazepam $(1.25 \mathrm{mg} / \mathrm{kg})$ and $\mathrm{SH}-053-\mathrm{S}-\mathrm{CH} 3$ $(10,20$ and $30 \mathrm{mg} / \mathrm{kg})$ on the (a) distance travelled on open arms, (b) percentage of entries in open arms and (c) percentage of time spent on open arms of the EPM. Number of animals per treatment (for $\mathrm{SOL}$ through $\mathrm{SH}-053-\mathrm{S}-\mathrm{CH} 330 \mathrm{mg} / \mathrm{kg}$, respectively): 6, 6, 5, 6, 6. *p $<0.05$ compared to solvent (SOL) group.

monitoring $(\mathrm{F}(4,31)=2.73, p=0.047)$ (Figure 5, hatched bars). The respective $p$ values for diazepam $1.25 \mathrm{mg} / \mathrm{kg}$, SH-053-S-CH3 $30 \mathrm{mg} / \mathrm{kg}$, SH-053-S-CH3-2'F $30 \mathrm{mg} / \mathrm{kg}$, and SH-053-R-CH3 $30 \mathrm{mg} / \mathrm{kg}$ were $0.491,0.029,0.067$, and 0.207 , related to solvent. According to ANOVA, the influence of treatment on activity in peripheral parts of the chamber (Figure 5, open bars) was more distinct: $\mathrm{F}(4.31)=3.59$, $p=0.016$; all the four treatments significantly decreased activity when related to control by Dunnett's test.

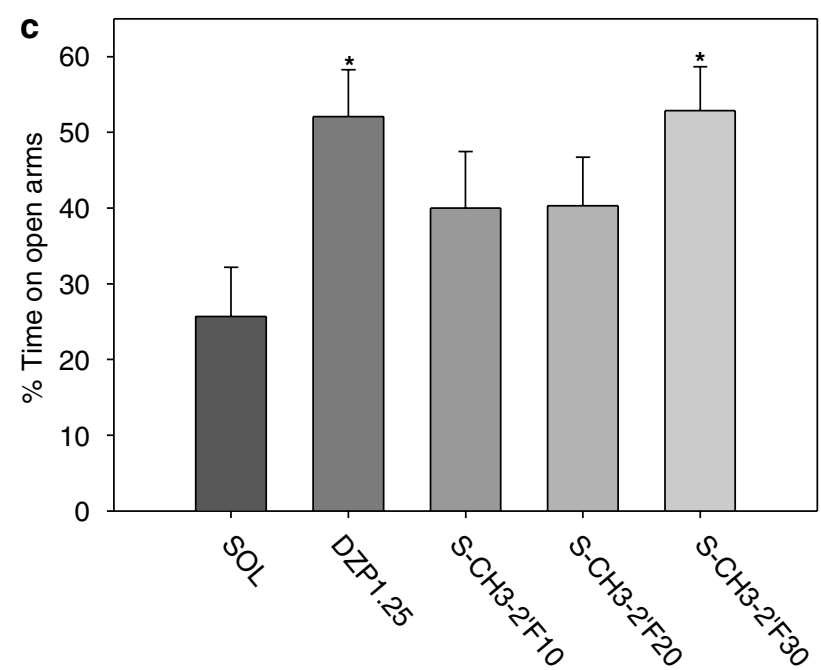

Figure 4 The effects of diazepam $(\mathrm{I} .25 \mathrm{mg} / \mathrm{kg})$ and $\mathrm{SH}-053-\mathrm{S}-\mathrm{CH} 3-2^{\prime} \mathrm{F}$ $\left(\mathrm{I}, 20\right.$ and $30 \mathrm{mg} / \mathrm{kg}$, designated as $\left.\mathrm{S}-\mathrm{CH} 3-2^{\prime} \mathrm{F}\right)$ on the (a) distance travelled on open arms, (b) percentage of entries in open arms and (c) percentage of time spent on open arms of the EPM. Number of animals per treatment (for SOL through SH-053-S-CH3-2'F $30 \mathrm{mg} / \mathrm{kg}$ ) was 10. * $p<0.05$ compared to solvent (SOL) group.

Rotarod test: When one monitors the influence on rotarod performance as a quantal phenomenon (ie all or none effect), the minimal incapacitating doses of SH-053-S-CH3 and SH-053-S-CH3-2'F were $200 \mathrm{mg} / \mathrm{kg}$ for both substances. The median incapacitating doses of diazepam, SH-053S-CH3, and SH-053-S-CH3-2'F were 2.99, 213.67, and $218.80 \mathrm{mg} / \mathrm{kg}$, respectively. Due to the shortage of substance, the median incapacitating dose of $\mathrm{SH}-053-\mathrm{R}-\mathrm{CH} 3$ 


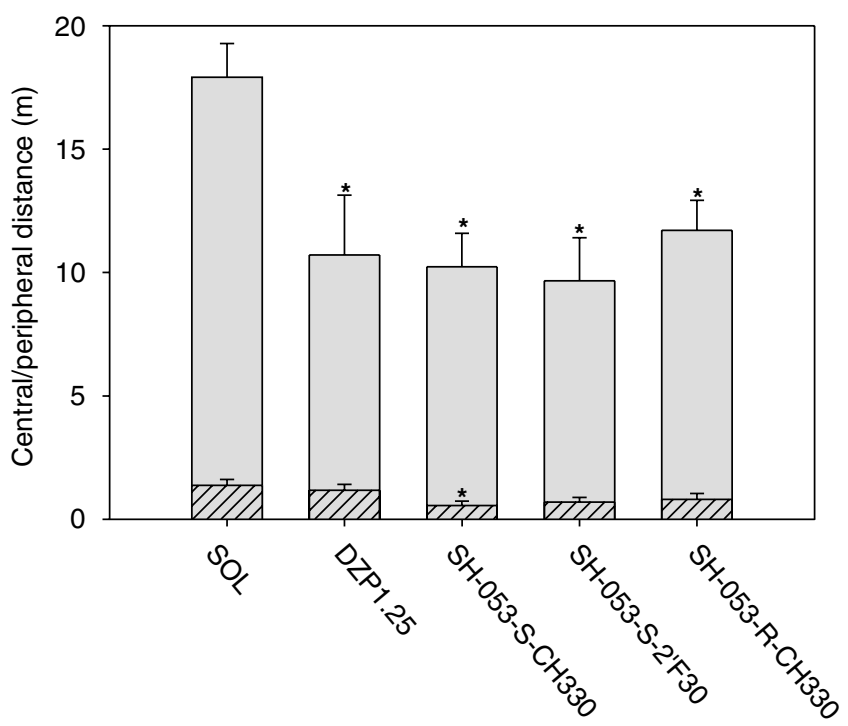

Figure 5 The effects of diazepam (I.25 mg/kg), SH-053-S-CH3 (30 mg/ $\mathrm{kg}), \mathrm{SH}-053-\mathrm{S}-\mathrm{CH} 3-2^{\prime} \mathrm{F}(30 \mathrm{mg} / \mathrm{kg}$, designated as SH-053-S-2'F) and $\mathrm{SH}-$ $053-\mathrm{R}-\mathrm{CH} 3(30 \mathrm{mg} / \mathrm{kg})$ on distance travelled in the central (hatched bars) and peripheral (open bars) zone of the activity chamber during $45 \mathrm{~min}$ of recording (total activity corresponds to the height of the whole bar). *p $<0.05$ compared to solvent (SOL) group. Number of animals per treatment (Figures 5 and 6) for SOL through SH-053-S-CH3-2'F $30 \mathrm{mg} / \mathrm{kg}$ was 8 , and 4 for $\mathrm{SH}-053-\mathrm{R}-\mathrm{CH} 3$.

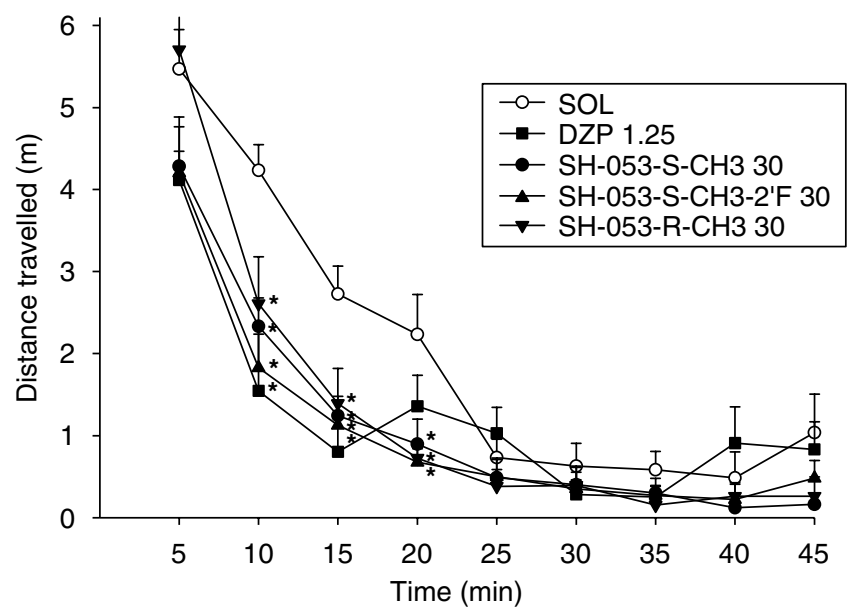

Figure 6 The effects of diazepam (I.25 mg/kg), SH-053-S-CH3 (30 mg/ $\mathrm{kg}), \mathrm{SH}-053-\mathrm{S}-\mathrm{CH} 3-2^{\prime} \mathrm{F}(30 \mathrm{mg} / \mathrm{kg})$ and $\mathrm{SH}-053-\mathrm{R}-\mathrm{CH} 3(30 \mathrm{mg} / \mathrm{kg})$ on the distance travelled in 5 min intervals in the activity assay. ${ }^{*} p<0.05$ compared to solvent $(\mathrm{SOL})$ group.

was not found; at doses up to $100 \mathrm{mg} / \mathrm{kg}$ it did not induce any manifest incapacitation in this test.

\section{DISCUSSION}

The present experiments demonstrated the anxiolytic potential of two newly synthesized compounds functionally selective for $\alpha 2-, \alpha 3-$, and $\alpha 5$-containing $\mathrm{GABA}_{\mathrm{A}}$ receptors, $\mathrm{SH}-053-\mathrm{S}-\mathrm{CH} 3$, and $\mathrm{SH}-053-\mathrm{S}-\mathrm{CH} 3-2^{\prime} \mathrm{F}$, which is mainly devoid of ataxic, but not of sedative actions characteristic of nonselective BZs. Furthermore, a stereoisomer of SH-053-S-
$\mathrm{CH} 3$ functionally selective for $\mathrm{GABA}_{\mathrm{A}}$ receptors containing the $\alpha 5$ subunit, $\mathrm{SH}-053-\mathrm{R}-\mathrm{CH} 3$, exerted in the locomotor activity paradigm a significant hypolocomotor effect comparable to diazepam, without observable anti-anxiety or ataxic activity in the EPM, and rotarod test, respectively.

These findings were somewhat unexpected, since both motor incoordination and sedation have been ascribed to the $\alpha 1$ subunit-mediated action of diazepam (Rudolph et al, 1999; McKernan et al, 2000). Hence, either these three compounds were not silent at the $\alpha 1$ subtype when dosed at $30 \mathrm{mg} / \mathrm{kg}$, or some non- $\alpha 1$-subunit-containing receptors contribute to the hypolocomotor action of BZ site agonists. Although the absence of occupancy data for distinct receptor subtypes precludes drawing firm conclusions, high minimal incapacitating doses of the present functionally selective ligands in the rotarod test could be seen as indirect evidence for lack of involvement of $\mathrm{GABA}_{\mathrm{A}}$ receptors containing the $\alpha_{1}$ subunit in behavioral actions of $30 \mathrm{mg} / \mathrm{kg}$ doses. Specifically, diazepam-induced loss of motor coordination in the rotarod test was linked to the $\alpha 1$ subunit (Crestani et al, 2000; McKernan et al, 2000), and the sevenfold differences in effective doses of $\mathrm{SH}-053-\mathrm{S}-\mathrm{CH} 3$ and $\mathrm{SH}-053-\mathrm{S}-\mathrm{CH} 3-2^{\prime} \mathrm{F}$ in rotarod $v s$ SLA test could hardly exist if substantial modulation at $\alpha 1$ subunit containing $\mathrm{GABA}_{\mathrm{A}}$ receptors were attained already at $30 \mathrm{mg} / \mathrm{kg}$. However, there may exist marked differences in fractional occupancy of $\mathrm{GABA}_{\mathrm{A}}$ receptors containing the $\alpha_{1}$ subunit needed for producing behavioral effects of a $\mathrm{BZ}$ site agonist in these two tests, meaning that low-to-moderate modulation at such receptors is sufficient for eliciting sedative, but not rotarod-incapacitating, action (cf. Facklam et al, 1992). Nevertheless, the latter explanation is not highly probable for the tested ligands with very low efficacies at $\alpha 1$ containing subtypes. Namely, even the preferential $\alpha 1$ subunit-selective agonist, zolpidem, does not possess more than 4.3 and 2.5 times greater potency to decrease locomotor activity compared to rotarod impairment in rats and mice, respectively (Sanger et al, 1996), whereas nonsubtype-selective agonists, such as diazepam, may be even more potent in exerting rotarod impairment than locomotor hypoactivity (Savić et al, 2003).

In its broadest sense, sedation involves decreased psychomotor and cognitive performance, and in most instances it is considered an adverse effect of psychotropic drugs, which should be avoided. In animals, the psychomotor component is most frequently studied (Bourin and Briley, 2004), and measurement of motor activity in rodents represents a standard behavioral assay for testing the sedative potential of drugs (Vogel, 2002). In fact, sensitivity of preclinical tests for discerning the sedative potential of a drug is of paramount importance; several BZ site partial agonists developed as putative low-sedative anxiolytics have nevertheless appeared to be incapacitating when subsequently tested in humans (Whiting, 2006). In support of the sensitivity of the standard SLA test used in the present study, Dailly et al (2002) observed a sedative effect of diazepam $(1 \mathrm{mg} / \mathrm{kg}$ i.p.) in the actimeter, but not in the light-dark test of anxiety, which also measured locomotor activity of mice. In accordance, SH-053-S-CH3, SH-053-2 ${ }^{\prime}$ $S-\mathrm{CH} 3$, and $\mathrm{SH}-053-\mathrm{R}-\mathrm{CH} 3$, all dosed at $30 \mathrm{mg} / \mathrm{kg}$, exerted a statistically significant depression of locomotion in the SLA test in our study, whereas the influence on the standard 
activity parameters in the EPM (closed-arm entries and total distance travelled), if any, was far from significant. It should be emphasized that the hypolocomotor influence in the SLA test is also evident when separately analyzing activity in the peripheral zone of the chamber. Hence, the observed motor depressant effects of the tested ligands were not dependent on central zone activity, which is confounded by influences on emotional reactivity, that is, anxiety, and could be seen as a pure measure of sedation (cf. Savić et al, 2006). These results further support the routine use of the SLA test (Bourin and Briley, 2004; Vogel, 2002) in efforts to predict clinical sedation.

On the other hand, it is noticeable that standard studies of motor activity, which form the very basis of knowledge of drug effects on behavior (Kelley, 1993), were not employed for characterization of recently reported putative anxioselective compounds (Atack et al, 2006c; Jennings et al, 2006; Griebel et al, 2001; Russell et al, 2006). Jennings et al (2006) reported on an $\alpha 2 / \alpha 3-\mathrm{BZ}$ site-selective ligand from the class of imidazo[1,2-b][1,2,4]triazines with anxiolytic activity in the rat EPM test at the dose of $1 \mathrm{mg} / \mathrm{kg}$, which showed no motor incapacitation in the mouse rotarod test at doses up to $30 \mathrm{mg} / \mathrm{kg}$. A close congener of that compound was anxiolytic in the rat EPM test at $3 \mathrm{mg} / \mathrm{kg}$, whereas it showed no significant activity in a surrogate assay of sedation (chain-pulling test in rats) and in the mouse rotarod test when tested in doses up to $10 \mathrm{mg} / \mathrm{kg}$; reportedly, this compound was chosen as a clinical candidate (Russell et al, 2006). Similarly, a 1,2,4-triazolo[4,3-b]pyridazine, TPA023, exerted anxiolytic-like activity in the rat EPM and fearpotentiated startle tests at the dose of $1 \mathrm{mg} / \mathrm{kg}$ as well as in the assay of conditioned suppression of drinking at $3 \mathrm{mg} / \mathrm{kg}$, whereas, at doses up to $30 \mathrm{mg} / \mathrm{kg}$, it did not significantly affect behavior of rats in the chain-pulling test nor rotarod performance of mice (Atack et al, 2006c). However, the same experimental group, when testing pagoclone, detected sedative action of this BZ site agonist dosed at $1 \mathrm{mg} / \mathrm{kg}$ in the chain-pulling test, while already at $0.3 \mathrm{mg} / \mathrm{kg}$ in the SLA test (Atack et al, 2006b). The very high dose $(10 \mathrm{mg} / \mathrm{kg})$ of diazepam used as the active control in the chain-pulling test (Atack et al, 2006b) additionally supports the view of superior sensitivity of the standard SLA test.

From these reasons, it is difficult to compare behavioral profiles of the compounds described in the present paper with findings from the above-cited studies. Evidently, all three newly synthesized $\mathrm{BZ}$ site ligands could have acted through the $\alpha_{5}$ subtype-containing $\mathrm{GABA}_{\mathrm{A}}$ receptors, one of them (SH-053- $R-\mathrm{CH} 3)$ as an essentially subtype-selective ligand. There exist data that support the possibility of substantial motor manifestations of $\alpha 5$-containing $\mathrm{GABA}_{\mathrm{A}}$ receptor modulation, besides the indirect consequences brought on by the effects on learning and memory processes, where pertinent (Collinson et al, 2002; Crestani et al, 2002). Somatic and preganglionic motoneurons in the spinal cord exhibit a moderate-to-strong staining for the $\alpha 5$ subunit (Bohlhalter et al, 1996), whereas the knock-in mice harboring the $\alpha 5$ subunit insensitive to diazepam are refractory to development of tolerance to the sedative effect of diazepam dosed subchronically, presumably due to a downregulation of $\alpha 5$ subunits in the dentate gyrus (van Rijnsoever et al, 2004). Hence, we hypothesize that any locomotor activity changes induced by ligands possessing a substantial $\alpha 5$-efficacy may be, at least partly, contributed by modulation at $\mathrm{GABA}_{\mathrm{A}}$ receptors containing this subunit. Nevertheless, as a caveat to all studies examining sedation, it should be remembered that a decrease in automatically measured locomotor activity can be due to a variety of causes other than sedation, including the occurrence of stereotyped behavior, motor impairments or pain (Porsolt et al, 1993). In addition, particular caution is needed when transposing in vitro data to the in vivo conditions. Atack et al (2006a) reported on substantial decrease of the $\alpha 5$ subtype-binding selectivity of the $\mathrm{BZ}$ site inverse agonist RY-080 (Liu et al, 1995) when binding was tested in vivo; since RY-080 exerted appreciable inverse agonist-efficacy at the $\alpha 1$-containing $\mathrm{GABA}_{\mathrm{A}}$ receptors (Atack et al, 2006a), interpretation of behavioral actions of such functionally nonselective ligands is especially hindered. To dissect these overlaps in activity and uncertainties, much is expected from screening of newer BZ site ligands in the future, which will be still more functionally selective than those presented in this work.

In conclusion, the present results confirm the highly diminished ataxic potential of BZ site agonists devoid of $\alpha_{1}$ subunit-mediated effects. Anti-anxiety activity of such ligands remains preserved, whereas the confounding sedation stays observable, and may be partly dependent on the $\alpha_{5}$-containing $\mathrm{GABA}_{\mathrm{A}}$ receptors. Hence, it could be of importance to avoid substantial potentiation through the $\alpha_{5}$ subunits by the candidate anxioselective anxiolytics, if the clinical sedation is to be prevented.

\section{ACKNOWLEDGEMENTS}

This work was supported in part by NIMH 46851 (JMC) and by The Ministry of Science and Environment Protection, $\mathrm{R}$ Serbia-Grant No. 145022B (MMS). We acknowledge the support of this work by the Research Growth Initiative of the University of Wisconsin-Milwaukee.

\section{REFERENCES}

Atack JR, Bayley PJ, Fletcher SR, McKernan RM, Wafford KA, Dawson GR (2006a). The proconvulsant effects of the GABA(A) alpha5 subtype-selective compound RY-080 may not be alpha5mediated. Eur J Pharmacol 548: 77-82.

Atack JR, Pike A, Marshall G, Stanley J, Lincoln R, Cook SM et al (2006b). The in vivo properties of pagoclone in rat are most likely mediated by $5^{\prime}$-hydroxy pagoclone. Neuropharmacology 50: 677-689.

Atack JR, Wafford KA, Tye SJ, Cook SM, Sohal B, Pike A et al (2006c). TPA023 [7-(1,1-dimethylethyl)-6-(2-ethyl-2H-1,2,4-triazol-3-ylmethoxy)-3-(2-fluoropheny 1)-1,2,4-triazolo[4,3-b]pyridazine], an agonist selective for alpha2- and alpha3-containing $\mathrm{GABA}_{\mathrm{A}}$ receptors, is a nonsedating anxiolytic in rodents and primates. J Pharmacol Exp Ther 316: 410-422.

Basile AS, Lippa AS, Skolnick P (2004). Anxioselective anxiolytics: can less be more? Eur J Pharmacol 500: 441-451.

Bohlhalter S, Weinmann O, Möhler H, Fritschy JM (1996). Laminar compartmentalization of $\mathrm{GABA}_{\mathrm{A}}$-receptor subtypes in the spinal cord: an immunohistochemical study. J Neurosci 16: 283-297.

Bourin M, Briley M (2004). Sedation, an unpleasant, undesirable and potentially dangerous side-effect of many psychotropic drugs. Hum Psychopharmacol 19: 135-139.

Chang Y, Wang R, Barot S, Weiss DS (1996). Stoichiometry of a recombinant $\mathrm{GABA}_{\mathrm{A}}$ receptor. J Neurosci 16: 5415-5424. 
Collinson N, Kuenzi FM, Jarolimek W, Maubach KA, Cothliff R, Sur $C$ et al (2002). Enhanced learning and memory and altered GABAergic synaptic transmission in mice lacking the alpha 5 subunit of the $\mathrm{GABA}_{\mathrm{A}}$ receptor. $J$ Neurosci 22: 5572-5580.

Crestani F, Keist R, Fritschy JM, Benke D, Vogt K, Prut L et al (2002). Trace fear conditioning involves hippocampal alpha5 GABA(A) receptors. Proc Natl Acad Sci USA 99: 8980-8985.

Crestani F, Martin JR, Möhler H, Rudolph U (2000). Resolving differences in $\mathrm{GABA}_{\mathrm{A}}$ receptor mutant mouse studies. Nat Neurosci 3: 1059.

Dailly E, Hascoet M, Colombel MC, Jolliet P, Bourin M (2002). Relationship between cerebral pharmacokinetics and anxiolytic activity of diazepam and its active metabolites after a single intra-peritoneal administration of diazepam in mice. Hum Psychopharmacol 17: 239-245.

Dias R, Sheppard WF, Fradley RL, Garrett EM, Stanley JL, Tye SJ et al (2005). Evidence for a significant role of alpha 3-containing $\mathrm{GABA}_{\mathrm{A}}$ receptors in mediating the anxiolytic effects of benzodiazepines. J Neurosci 25: 10682-10688.

Facklam M, Schoch P, Bonetti EP, Jenck F, Martin JR, Moreau JL et al (1992). Relationship between benzodiazepine receptor occupancy and functional effects in vivo of four ligands of differing intrinsic efficacies. J Pharmacol Exp Ther 261: $1113-1121$.

Fuchs K, Zezula J, Slany A, Sieghart W (1995). Endogenous $\left[{ }^{3} \mathrm{H}\right]$ flunitrazepam binding in human embryonic kidney cell line 293. Eur J Pharmacol 289: 87-95.

Griebel G, Perrault G, Simiand J, Cohen C, Granger P, Decobert M et al (2001). SL651498: an anxioselective compound with functional selectivity for alpha2-and alpha3-containing gammaaminobutyric acid(A) (GABA(A)) receptors. J Pharmacol Exp Ther 298: 753-768.

He X, Huang Q, Ma C, Yu S, McKernan R, Cook JM (2000). Pharmacophore/receptor models for GABA(A)/BzR $\alpha 2 \beta 3 \gamma 2$, $\alpha 3 \beta 3 \gamma 2$ and $\alpha 4 \beta 3 \gamma 2$ recombinant subtypes. Included volume analysis and comparison to $\alpha 1 \beta 3 \gamma 2, \alpha 5 \beta 3 \gamma 2$, and $\alpha 6 \beta 3 \gamma 2$ subtypes. Drug Des Discov 17: 131-171.

Jennings AS, Lewis RT, Russell MG, Hallett DJ, Street LJ, Castro JL et al (2006). Imidazo[1,2-b][1,2,4]triazines as alpha2/alpha3 subtype selective GABA A agonists for the treatment of anxiety. Bioorg Med Chem Lett 16: 1477-1480.

Kelley AE (1993). Locomotor activity and exploration. In: van Haaren F (ed). Techniques in the Behavioral and Neural Sciences, vol 10. Methods in Behavioral Pharmacology. Elsevier: New York. pp 499-518.

Lader MH (1999). Limitations on the use of benzodiazepines in anxiety and insomnia: are they justified? Eur Neuropsychopharmacol 9(Suppl 6): S399-S405.

Licata SC, Platt DM, Cook JM, Sarma PV, Griebel G, Rowlett JK (2005). Contribution of $\mathrm{GABA}_{\mathrm{A}}$ receptor subtypes to the anxiolytic-like, motor, and discriminative stimulus effects of benzodiazepines: studies with the functionally selective ligand SL651498 [6-fluoro-9-methyl-2-phenyl-4-(pyrrolidin-1-yl-carbonyl)-2,9-dihydro-1H-pyridol[ 3,4-b]indol-1-one]. J Pharmacol Exp Ther 313: 1118-1125.

Liu R, Zhang P, McKernan RM, Wafford K, Cook JM (1995). Synthesis of novel imidazobenzodiazepines selective for the $\alpha 5 \beta 2 \gamma 2$ (Bz5) $\mathrm{GABA}_{\mathrm{A}} /$ benzodiazepine receptor subtype. Med Chem Res 5: 700-709.

Low K, Crestani F, Keist R, Benke D, Brunig I, Benson JA et al (2000). Molecular and neuronal substrate for the selective attenuation of anxiety. Science 290: 131-134.
McKernan RM, Rosahl TW, Reynolds DS, Sur C, Wafford KA, Atack JR et al (2000). Sedative but not anxiolytic properties of benzodiazepines are mediated by the $\mathrm{GABA}(\mathrm{A})$ receptor alpha1 subtype. Nat Neurosci 3: 587-592.

Porsolt RD, McArthur RA, Lenegre A (1993). Psychotropic screening procedures. In: van Haaren $\mathrm{F}$ (ed). Techniques in the Behavioral And Neural Sciences, vol 10. Methods in Behavioral Pharmacology. Elsevier: New York. pp 23-51.

Rowlett JK, Platt DM, Lelas S, Atack JR, Dawson GR (2005). Different $\mathrm{GABA}_{\mathrm{A}}$ receptor subtypes mediate the anxiolytic, abuse-related, and motor effects of benzodiazepine-like drugs in primates. Proc Natl Acad Sci USA 102: 915-920.

Rudolph U, Crestani F, Benke D, Brunig I, Benson JA, Fritschy JM et al (1999). Benzodiazepine actions mediated by specific gamma-aminobutyric acid(A) receptor subtypes. Nature 401: 796-800.

Rudolph U, Möhler H (2004). Analysis of $\mathrm{GABA}_{\mathrm{A}}$ receptor function and dissection of the pharmacology of benzodiazepines and general anesthetics through mouse genetics. Annu Rev Pharmacol Toxicol 44: 475-498.

Rudolph U, Möhler H (2006). GABA-based therapeutic approaches: $\mathrm{GABA}(\mathrm{A})$ receptor subtype functions. Curr Opin Pharmacol 6: 18-23.

Russell MG, Carling RW, Street LJ, Hallett DJ, Goodacre S, Mezzogori E et al (2006). Discovery of imidazo[1,2-b][1,2,4]triazines as GABA(A) alpha2/3 subtype selective agonists for the treatment of anxiety. J Med Chem 49: 1235-1238.

Sanger D, Willner P, Bergman J (2003). Applications of behavioural pharmacology in drug discovery. Behav Pharmacol 14: 363-367.

Sanger DJ, Morel E, Perrault G (1996). Comparison of the pharmacological profiles of the hypnotic drugs, zaleplon and zolpidem. Eur J Pharmacol 313: 35-42.

Savić MM, Obradoviæ DI, Ugrešiæ ND, Bokonjiæ DR (2003). The influence of diazepam on atropine reversal of behavioural impairment in dichlorvos-treated rats. Pharmacol Toxicol 93: 211-218.

Savić MM, Obradović DI, Ugrešiæ ND, Cook JM, Yin W, Van Linn $\mathrm{M}$ et al (2006). Benzodiazepine site inverse agonists and locomotor activity in rats: bimodal and biphasic influence. Pharmacol Biochem Behav 84: 35-42.

Sieghart W, Sperk G (2002). Subunit composition, distribution and function of $\mathrm{GABA}_{\mathrm{A}}$ receptor subtypes. Curr Opin Med Chem 2: 795-816.

Sigel E (1987). Properties of single sodium channels translated by Xenopus oocytes after injection with messenger ribonucleic acid. J Physiol 386: 73-90.

Sigel E, Baur R, Trube G, Möhler H, Malherbe P (1990). The effect of subunit composition of rat brain $\mathrm{GABA}_{\mathrm{A}}$ receptors on channel function. Neuron 5: 703-711.

Sigel E, Buhr A (1997). The benzodiazepine binding site of $\mathrm{GABA}_{\mathrm{A}}$ receptors. Trends Pharmacol Sci 18: 425-429.

van Rijnsoever C, Tauber M, Choulli MK, Keist R, Rudolph U, Möhler $\mathrm{H}$ et al (2004). Requirement of alpha5-GABA $\mathrm{A}_{\mathrm{A}}$ receptors for the development of tolerance to the sedative action of diazepam in mice. J Neurosci 24: 6785-6790.

Vogel HG (2002). Drug Discovery and Evaluation. Springer: Berlin.

Whiting PJ (2006). GABA-A receptors: a viable target for novel anxiolytics? Curr Opin Pharmacol 6: 24-29.

Zhang W, Koehler KF, Zhang P, Cook JM (1995). Development of a comprehensive pharmacophore model for the benzodiazepine receptor. Drug Des Discov 12: 193-248. 